\title{
Develop Aspect of the in Playing Traditional Angklung using a Combination Learning Models of Direct Instruction and Talking Sticks
}

\author{
Hj Noor Ramdana *, Nina Permata Sari, Aslamiah \\ Master Program of Early Childhood Teacher Education, Universitas Lambung Mangkurat, Banjarmasin \\ 70123, Indonesia
}

Article history:

Submission August 2020

Revised September 2020

Accepted September 2020

*Corresponding author:

E-mail:

hj.noorramdana@gmail.com

\begin{abstract}
The study aims to describe the activities of teachers and children and improve children's development outcomes in the art aspect of playing musical instruments (forming regular rhythms), a combination of Direct Instruction learning models, Talking Sticks, and traditional Angklung musical instrument media. This research uses the Classroom Action Research (CAR) method. Research settings in group B.2 Khadijatul Kubra Kindergarten, Banjarmasin City with a total of 15 children in the 2019/2020 school year, consisting of 7 boys and eight girls. Data obtained from observation techniques teacher activities, children, and the development of aspects of art. Indicators of teacher activities' success when obtaining a minimum score of 8 and a maximum score of 32. Children's activities are categorized as successful if the classical results reach $\geq 76 \%$ and above. The development of children's art reaches a minimum category as expected (BSH). Conclusion of the study: teacher activity reaches a score of 32 with a percentage of $100 \%$ the category of very good. The results of children's activities classically $87 \%$ of the category is very active, and the results of child development $\geq \star \star \star$ with the percentage of $87 \%$, the category develops in line with expectations (BSH) and develops very good (BSB).
\end{abstract}

Keywords: The art, playing traditional angklung, direct instruction, talking sticks

\section{Introduction}

All potential and intelligence and the basics of a person's behavior have begun to form at an early age. Brain development at an early age accelerates to $80 \%$ of the whole adult brain. It is also believed that the first thousand days of human life, from conception to a child's second birthday, is a critical period for the foundation of development potential, which is influenced by various factors (Cusick \& Georgieff, 2013). This period is so crucial that early age is often called the golden age (Coates \& Coates, 2006). Thus it can be concluded that in order to create a quality generation, education must be done early, through Early Childhood Education (Suyadi, 2010). For example, it is like during the medieval era in Japanese Buddhist monasteries, children have been constructed by social, occupational, and religious factors (Porath, 2017). It is seen as something similar to today's education. However, during the medieval era, children had been left to grow up on their own, while early modern children came to be seen as treasures to be carefully raised and educated (Walthall, 2017). As needed as education, children also need a supportive and caring family (Goldfarb, 2017). Besides, children's health in an early year is also considered to be essential to get attention (Rosenthal \& Lakhanpaul, 2020). To create a well behave and intelligent generation, all of these aspects are needed in early childhood life and education.

\section{How to cite:}

Ramdana, H. N., \& Sari, N. P. (2020). Develop aspects of the art in playing traditional angklung using a combinantion learning models of direct instruction and talking sticks. Journal of K6 Education and Management, 3 (3), 303 - 314 . doi: 10.11594/jk6em.03.03.03 
Education is an essential thing to be obtained by children or adults (Pala, 2011). Good education will help someone to face their future (Baharuddin \& Dalle, 2019). Education is one of the assets for someone to succeed and be able to achieve success in their lives (Galindo et al., 2007). It is fundamental for society's development and individuals' ability to grow and reach their potential (Christophersen, 2015). Thus, kindergarten Education is early education as a place to help children prepare for further development by building children's skills, knowledge, attitudes, and behavior (Sheridan et al., 2009).

According to Suriansyah \& Aslamiah (2011), Kindergarten Education is a form of early childhood education that plays a vital role in developing children's personalities and preparing them to enter the next level of education. Kindergarten children between the age of 4 and 6 years are the most sensitive to external stimuli. Children are still happy to play and have a high curiosity making it essential to receive stimuli from outside themselves to respond to various forms of play and learning patterns in the form knowledge (cognitive), skills (psychomotor), values and attitudes (affective) (Samuelsson et al., 2009).

In the opinion of Jhon Dewey, educational activities are necessarily a process of experience. However, this experience leads to inner growth, so that with this inner growth, the experience becomes the basis for growth and efforts to trigger the growth of children per their respective potentials and needs (Suriansyah, 2011). Hence, the teacher and student perceptions of their own experiences are essential to getting improvement and development (Cope $\&$ Ward, 2002) to lead children to their upmost inner potential and growth.

The foundations of brain development and functioning, and subsequent lifelong development, are laid down in early childhood in a process that is exquisitely sensitive to external influence (Thematic Group 4, 2014). The functional growth of nerve cells requires a variety of supportive educational situations, both in the situation of family, community, and school education. It is supported by the idea that, whether construed as home-based behaviors, school-based activities, or parent-teacher communication, parental involvement has been positively linked to student achievement (Hoover-Dempsey, et al., 2005). Family engagement in the education of young children is associated with numerous positive outcomes for those children. Parents and other family members play an important role as teachers during the time children spend outside the classroom (Daugherty et al., 2014).

It shows the importance of efforts to develop the full potential of children at preschool age. At that age, children experience a sensitive period, namely the maturation of physical and psychological functions that are ready to respond to stimuli provided by the environment. The environment is including the parent involvement in improving education (Drummond \& Stipek, 2004) of the children. The sensitive period is the time to lay the first foundation in developing the full potential of children, including their interests and talents in the arts (Eichsteller \& Holthoff, 2012).

One aspect of children's fundamental abilities that need to be developed, which will significantly affect growth and development in other aspects, is the development of art (Hallam, 2010). Art activities play a role in developing various necessary abilities in themselves, such as physical, perceptual, thinking/intellectual, emotional, creativity, social, and aesthetic abilities (Chen, 2016). As child ages, all necessary abilities can develop in an integrated way.

The success of art learning can be realized if teaching and learning activities can arouse learning motivation and are meant for children. Motivation has become the central concern of many (Rathunde \& Csikszentmihalyi, 2005). Factors such as curiosity and confidence in one's abilities (Alizadeh, 2016) as every child has a high curiosity (Gottfried, et al., 2016). Learning activities are inseparable from the teacher and child's role because these two components are essential in the learning process (Hidayat, Hadi, \& Darmiyati, 2019). Another factor in developing children's learning outcomes is teachers' ability to deliver learning materials that motivate and can coordinate children in the classroom (Metroyadi \& 
Mardhiah, 2018). In the modern era, like nowadays, digital learning is one of the examples that can be contributing to the students' or children's intrinsic motivations (Van Loon, Ros, \& Martens, 2012).

The teacher contributes to who deals directly with students through a process of instructional interaction as a vehicle for the learning process (Aslamiah, 2016) As a good teacher, needs to channel his curiosity through active and creative learning that is fun according to the interests and abilities of children (Oreck, 2006).

The teacher needs to do something for the class, manage the class well, use learning by giving examples and not examples, and improve learning outcomes so that developments in aspects of religious and moral values can develop properly to distinguish which actions are good and evil (Afifah, Suriansyah. A, \& Aslamiah, 2019). It is not only religious and moral values, but other aspects are also essential to be developed in children as early as possible as in aspects of children's art, which are also needed in every child's development.

An arts education perspective aims to further aesthetic education (McCutchen, 2006). Introducing Art Learning in early childhood can be done through play activities (Sullivan, 2018). An educator must be able to prepare children's play activities by preparing learning themes, learning materials, and media to implement activities. One of the learning materials that must be prepared by the teacher/educator is art. Traditionally, art is an integral part of early childhood learning programs. The art invites children to touch and experiment, explore and transform everything that children encounter in their daily lives. Thus, art is a medium that can help young children convey something (ideas/ideas, feelings, desires, imagination, etcetera.) that they are unable to express through words. Naturally, children already have the ability of art. Early childhood can already have and develop imagination (FLeer, 2011). A one-year-old child has started to beat anything. He began to study and absorb everything that happened in the surrounding environment. Every object played functions by the imagination of the child (Fleer, 2011). In art activities for children, educational values are determined, which are then known as the education through art concept proposed by Herbert Read, developed from Plato's thought (428-347 SM) (Meeson, 1974).

Kindergarten age children are at a pre-operational level of thinking. In order for art learning in kindergarten to be meaningful and beneficial for children, efforts are needed to deliver material and implement multidimensional, multilingual, multidisciplinary, and multicultural art activities through approaches to learning with art, learning through art, and learning about art. Kindergarten teachers are required to use a variety of concrete learning media because learning media can provide more concrete direct learning experiences and develop critical and positive thinking skills.

Education in schools, especially in kindergarten, is expected not only to develop intelligence but also to develop aspects of religious and moral values, physical motor, cognitive, language, social, emotional, and arts. The development of art in education in kindergarten introduces various kinds of musical instruments. From modern musical instruments and traditional musical instruments, they are not only introduced and explained but should be used directly by children, so that children can have a pleasant experience for children.

The child's action on object and observation of the object's reaction is both critical in all activities involving physical knowledge (Piaget, 1993). However, we see kinds of activities based on the relative importance of action and observation.

On this occasion, the researcher will provide knowledge of aspects of the development of art to students in the Khadijatul Kubra Kindergarten. Traditional musical instruments are an ancestral heritage that illustrates the identity of each region. Traditional angklung musical instruments originating from the province of West Java, angklung is played by shake per the tone. This type of music uses different languages and instruments, depending on the languages and instruments developed. Angklung learning includes instilling discipline, responsibility, creativity, and cooperation. The attitude of discipline is trained when the child follows the count. Cue from the teacher, an attitude of responsibility is formed when the child plays 
each note on each angklung that is part of it. The attitude of cooperation and creativity is formed when playing angklung together.

The researchers conducting research is to develop creativity in aspects of art, so far in kindergarten is more concerned with cognitive aspects, language, physical motor, and socialemotional even though aspects of art are also important. The aspect of art can develop intelligence or intelligence (Eisner, 2004), which is not only useful at the age of kindergarten alone but beneficial for the long term. The importance of developing aspects of art in kindergarten children is that children gain direct knowledge and experience, starting from the child holding, playing his instrument directly, and knowing where the musical instrument originated. Therefore, researchers are interested in developing aspects of art in children.

Based on observations made in March 2019 , the cause was that the teacher only introduced various musical instruments through pictures or videos, without the media and without presenting the objects directly. Therefore the child only knew the angklung instrument as a medium of play and was merely explained by the teacher without direct learning or direct practice. The supporting factors are adequate means of learning angklung traditional music. Even though each child has different abilities, interests, and talents, students are happy with the existence of traditional angklung music learning and are directly involved in playing it.

Despite sensitivity and curiosity about sound, children still like to play (Ilmim, 2018). Discipline, responsibility, and cooperation can also be formed through this learning. Angklung traditional music playing techniques by being shaken by direct instruction by the teacher. The lack of teacher knowledge on traditional angklung instruments and how the learning process is monotonous, makes learning ineffective $(A H, 2018)$. Limited time in implementation also makes learning not implemented well. Angklung traditional music learning is only given once a month on Saturdays with a relatively short time of about 60 minutes or just to interlude in an extracurricular program at the Kindergarten Khadijatul Kubra. In the introduction of musical instruments, children are only introduced to modern musical instruments such as keyboards, pianos, guitars in general, and their knowledge of traditional musical instruments is lacking.

At the same time, children need to be directly involved in learning. One way to activate the child is to use a combination of learning that can motivate, arouse interest, activeness, and develop children's abilities in learning by making them involved directly in learning. Because then they will quickly understand the lessons learned taught (Fatmasari, Darmiyati, \& Sulaiman, 2015). Therefore, researchers want to conduct research using the medium of traditional angklung musical instruments combined with direct instruction and talking stick learning models. It is expected that children's abilities, skills and knowledge, and intelligence can develop optimally and experience an increase in children's development achievements while introducing traditional musical instruments which we must instill early on. In the end, the children can play by direct practice per the direction of the teacher/educator who can develop aspects of art.

Understanding the direct instruction model is a systematic learning model. Direct learning, formal and non-formal, provides a disciplined structure, and learning becomes meaningful and systematic (Rogers, 2014). Direct learning based on children's experiences is an approach to learning where children stay involved and focused while achieving desired learning outcomes. They are designed for all learning-oriented groups with an emphasis on factual knowledge that is not time-bound.

It was understanding that the learning stick talking model is done with the help of a stick. The stick is used as a ration or turns to argue or answer questions from the teacher after the child learns the subject matter (Kurniasih \& Sani, 2015). Talking Stick is a learning model useful for training the courage of students in answering and talking to others. The use of sticks turn as a medium to stimulate students to act quickly and appropriately as well as to measure the ability of students to understand the material (Maufur, 2009)

Based on the research results (Erviana, Ahmad, \& Sari, 2020), using a combination of 
conversational methods, demonstrations and pictures, and picture learning models, and talking sticks with number card media successfully developing children's cognitive abilities.

After careful observation and adaptation to learning in kindergarten, combining the application of direct instruction and talking stick learning models using traditional angklung instruments in Group B.2 Khadijatul Kubra Kindergarten is expected to develop aspects of children's art in playing musical instruments making regular rhythm. The research will be entitled "Developing the Art Aspect of Playing Musical Instruments (Forming Regular Rhythm) Using a Combination of Direct Instruction Learning Model and Talking Stick with Media of Traditional Angklung Musical Instrument in Group B.2 Khadijatul Kubra Kindergarten. After careful observation and adaptation to learning in kindergarten, the combination of the application of a combination of direct instruction and talking stick learning models using traditional angklung instruments in Group B.2 Khadijatul Kubra Kindergarten is expected to develop aspects of children's art in playing musical instruments making regular rhythm. Based on the background statement, the research will examine more deeply about "Developing the Art Aspect of Playing Musical Instruments (Forming Regular Rhythm) Using a Combination of Direct Instruction Learning Model and Talking Stick with Media Traditional Angklung Musical Instrument in Group B.2 Khadijatul Kubra Kindergarten Kota Banjarma$\sin "$.

Researchers hope to be able to provide inspiration to Teachers / Educators in teaching and learning activities and make young children as Nimble, talented, creative, disciplined, independent, confident, and noble people. Angklung music can be used in an integrated curriculum to enhance development, such as religious and moral values, physical motor, cognitive, language, social, emotional, and arts.

\section{Material and Methods}

The study was conducted at Khadijatul Kubra Kindergarten, located at Jalan Keramat Basirih No. 65 RT.09 RW.01 Basirih SubDistrict, West Banjarmasin, Banjarmasin City, South Kalimantan 70245. The research subjects were class B2, amounting to 15 children consisting of 8 girls and seven boys. This class action research procedure was carried out in two cycles, each cycle consisting of two meetings. Each meeting includes four stages, namely, planning, implementation, observation, and reflection.

Data analysis is through the activities of teachers, children, and the results of children's language development. In this study, indicators of success are considered successful if the teacher's activity scores with a range between 20-24 with excellent criteria. Children's activities reach $\geq 76 \%$ with the category of very active and the ability to play musical instruments (forming a regular rhythm) can be said to develop if classical achieve minimal success $\star \star \star$ (Develop according to expectations) or achieve $\geq \star \star \star \star$ (develop very well).

\section{Results and Discussion Teacher activities}

At each meeting conducted, there is always an increase in the score of teacher activity, starting at meeting 1 , which scores 21 percentages of $65.62 \%$ with the Good category. At meeting 2 who scores 26 percentages $81.25 \%$ with the Good category, continued at meeting 3 who got a score of 29 percentages of $90.62 \%$ with the category of Very Good, until the 4th meeting which finally reached an indicator of success which got a score of 32 percentages of 99.99\% with the category of Very Good.

The increase is an improvement made by the teacher at each meeting by looking at the deficiencies that exist when doing learning activities. By seeing these deficiencies, the teacher can make improvements for development, which in turn, the teacher can achieve the expected results by reaching the category Very good at meetings 3 and 4. Besides, it is also influenced by the way the teacher slowly provides guidance and patiently helps the child when experiencing difficulties. The teacher also directs and gives motivation to the child.

The results above show that children are motivated by their teachers to carry out their tasks productively and effectively. According to (Sujiono, 2013), the teacher's attitude who can be a friend of the child also makes the child's 
ability to socialize more quickly formed, the encouragement of the teacher helps children who lack the confidence to learn to play together with their friends. According to (Sanjaya, 2009), teachers in learning activities have an essential role because children are developing individuals who need guidance and assistance from adults.

Creating a learning environment that can support the effectiveness and efficiency of children's learning is inseparable from the role of the teacher as a person who manages a pleasant learning environment for children. According to (Suriansyah \& Aslamiah, 2011), in the process of child development, as expected, the teacher has a crucial and strategic role in fostering kindergarten age children's level of development. According to (Aslamiah, 2016), one of the factors of the many factors that support the quality of education is the teacher factor. Educators should be able to create a new learning atmosphere so that children are not bored and fed up when receiving learning. Using current technology can be a good idea in making learning activities more fun (Davison \& Lazaros, 2015). The teacher is a figure that deals directly with the child through the process of interaction in learning.

The teacher must know correctly and effectively the tasks and work that must be mastered in managing the learning environment available in the school environment, as an element that is directly involved in the learning process with children (Sakerebau, 2018) For this reason. Teachers must apply a variety of learning strategies. Creativity is indeed needed to make variations in learning activities. Information concepts, ways of thinking, social values, and others are the goals of teaching models that make children active in learning. The model centers on the delivery of the teacher, while some others try to focus on the child's response in doing the tasks and positions of the child as partners in the learning process (Huda, 2014)

According to (Baiti, Metroyadi., \& Wahyu, 2019), The role of teachers and parents is significant in the development of children, especially in understanding the child's golden period as early as possible. When conducting this research, the teacher found many benefits, including the teacher being able to understand that children will be more active when children are directly involved in these activities. The use of new media will foster children's attention by directly training the child. Get their own experience, being a teacher does not only tell the activity, but the child immediately does it so that the inculcation of the independent attitude that the teacher wants to achieve can run optimally (Safitri, Ahmad, \& Saleh, 2018).

The teacher acts as a planner, learning designer, and as an implementat (Jimoyiannis, 2010). Therefore, teachers must understand the applicable curriculum, the characteristics of children, facilities, and available resources so that they are used as components in developing learning plans and designs (Sanjaya, 2009). In implementing the combined model steps in this study, the teacher is very concerned about all aspects that can support learning, one of which is the structuring of learning media and environmental structuring. Structuring the learning environment, the teacher must, in such a way, create a pleasant learning environment so that each child has equal access to learning.

Similar to parent-child interactions that children have with nonparental caregivers can play an essential role in promoting child development (Martin et al., 2014). The development itself is a process of ongoing changes in a person, including aspects of cognitive development, affective and psychomotor. Therefore, a teacher will not be able to determine an accurate learning strategy without knowing its development.

This study shows that the teacher has prepared the material and learning components in advance, as the theory described above. The teacher does not get significant obstacles in the learning process because it has been prepared and planned. So that the teacher's activity develops very well in this study, as evidenced by the teacher delivering the material using angklung traditional musical instrument media directly to implement learning effective and efficient. The teacher can make children understand and understand the implementation of learning. 
Developing children's artistic abilities is to make good learning plans by paying attention to methods and models of learning that are appropriate to the growth, development, and individual needs of children.

\section{Children's activities}

Based on the results of observations, an increase in children's activity with steps that have been adapted to the child's developmental achievements and classically gets a very very active category. Children's activities at each meeting are less active, and quite active categories tend to decrease. At each meeting, also the children's activities increasingly reach active and very active categories, which is an indicator of expected success.

At the first meeting of children's activities classically get $42.33 \%$ with details in the category of less active 20\%, Quite Active 46.66\%, Active 33.33\%, and Very Active 0\%. At the second meeting of children's classic activities, get $13.33 \%$ with details in the category of Underactive, Moderately Active 26.66\%, Active 53.33\%, and Very Active 7\%. At the third meeting of children's activities classically get $67.33 \%$ with details in the category of Underactive $0 \%$, Moderately Active $26.66 \%$, Active 20\%, Very Active 53.33\%. Moreover, at the 4th meeting of children's activities, they classically get $83.33 \%$ with details in the category of Underactive $0 \%$, Enough Active 0\%, Active 26.66\%, and Very Active $73.33 \%$.

Children's activities are declared successful if the success achieved by children reaches a percentage range of $82 \%-100 \%$. In the implementation of Cycle II, the second meeting of children's activities classically gained $83.33 \%$. So it can be concluded that the children's activities in following the learning activities take place are declared successful.

An excellent teaching process should provide opportunities to work on their own or learn activities (Hamalik, 2005). According to (Kunandar, 2012) Indicators of children's activity can be seen from 1) the majority of children are active in learning; 2 children dominate) activity; 3 ) the majority of children can do the work given by the teacher. Early childhood is a generalization of the nation's successors in the future. Children are born with their potential and intelligence (Gale, 2005). Adults and the environment around children must be able to provide appropriate stimulation and per the needs and stages of child development (Brussoni et al., 2012).

Sigmund Freud said that childhood is very influential in the development of one's adult personality. Seeing the phrase Freud above shows the development of children from childhood will affect when the child is an adult. The experiences that children get indirectly will be embedded in a child (Hsi, 2007). Childhood is a time to lay the first foundation in developing physical, motor, cognitive, language, socialemotional abilities, self-concept, discipline, art, morals, and religious values (Citrowati, 2019). Therefore, conditions and stimulation are needed by the child's needs so that the child's growth and development are optimally achieved (Yus, 2011).

Curiosity and a strong enthusiasm for everything are prominent features in early childhood, especially children aged 4-6 years (Spektor-Levy, Baruch, \& Mevarech, 2013). Children have a healthy attitude of adventure; among others, children will pay attention to, talk about, or ask questions about various things that could be seen or heard (Susanto, 2015). The teacher should be able to provide a learning activity that provides broad opportunities for children to be active and creative, both physically and mentally. The learning model that is used direct instruction and talking sticks with traditional angklung musical instruments that can develop art in forming regular rhythms.

In cycle I, the drill method was applied, students who were in the lacking category, the score increased to $77.33 \%$, and had not met the success criteria, so it needed to be continued with Cycle II action. In Cycle II, all students were in the good category with a score of $85.66 \%$ in applying the drill method.

\section{Art development results}

Based on the results of observations, an increase in the results of the development of art then obtained a comparison of each meeting experienced a significant increase because it has reached the specified success indicator that 
is getting $\star \star \star \star$ with a very well developed category (BSB). At the meeting of 1 child who received $\star 40 \%$ star, $\star \star 13 \%$ star, $\star \star \star$ $47 \%$ star, $\star \star \star \star 0 \%$ star. So that in meeting 1 the completeness of children reached $46.66 \%$, which totaled 7 children, while those who had not reached the completeness were $53.33 \%$, which totaled 8 people. Then at the meeting of 2 children who get stars $\star 0 \%$, stars $\star \star 40 \%$, stars $\star \star \star 13.33 \%$, stars $\star \star \star \star$ $46.66 \%$. So, meeting 2 completeness of children reached $60 \%$, amounted to 9 children, while those who have not reached completeness as much as $40 \%$ amounted to 6 people, furthermore, at the meeting of 3 children who received $\star 0 \%, \star \star 20 \%, \star \star \star$ $13.33 \%, \star \star \star \star 66.66 \%$. So, at meeting 3 completeness of children reached $80 \%$ amounted to 12 children, while those who have not reached completeness as much as $20 \%$ totaling 3 children. Finally at the meeting of 4 children who received $\star \& \star \star 0 \%, \star \star \star$ $13.33 \%, \star \star \star \star 86.66 \%$. So that at the 4 th meeting, the children's completeness reached $99.99 \%$, which amounted to 13 children by obtaining a very well developed category and 2 children by obtaining the development category as expected.

Implementation at meeting 1 and meeting 2 was said to be unsuccessful because it had not yet reached the indicator of success. Meeting 3 was said to be successful but not yet maximized and at meeting 4 it was said to be successful because it had achieved success and maximum $(\geq \star \star \star)$. So, it can be concluded that developing aspects of art in playing musical instruments (forming regular rhythms) using a combination of direct instruction learning models and talking sticks using traditional angklung instruments was declared victorious.

Based on this analysis, it can be seen that all aspects studied, namely teacher activities, children's activities, and the results of children's art development have increased at each meeting. In the aspect of teacher activity, every meeting tends to increase because the learning conducted by the teacher, every meeting has a quality that is getting better than before so that it gets the expected results. Likewise, in the aspect of children's activities that at every meeting is always increasing, it is because, during the learning process carried out at each meeting, the teacher can make children more active even very active at every meeting that is conducted. Therefore, the impact of this increased teacher activity and children's activity also increases the results of the development of art in children in each meeting. So it can be concluded that every aspect, namely aspects of teacher activities, children's activities, and children's learning outcomes are related to one another.

The results of the class action research obtained at meeting 1 , meeting 2 , meeting three and meeting 4 covering teacher activities, children's activities, and the development of art in the ability to play traditional angklung musical instruments can be seen through the following comparative analysis graph (Figure 1).

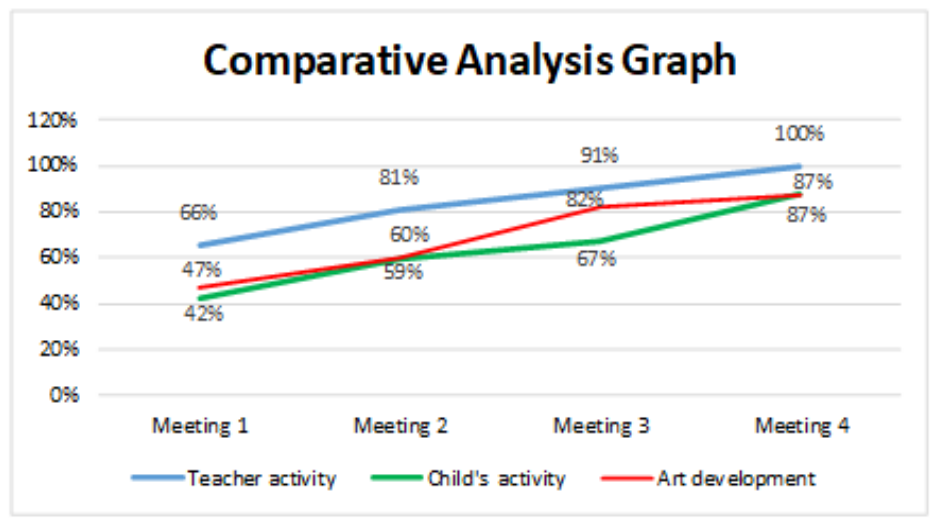

Figure 1. Graph analysis comparison of meetings 1-4

In learning activities, the teacher always conditions so that development results can be tries to regulate the learning situations and achieved per the expected goals. Teachers can 
carry out their role as managers of good learning so that learning for children becomes more meaningful (Hofstede, 1986). Children can learn directly, and children can know the procedures for playing traditional angklung musical instruments so that the results of the development of children's art will develop optimally. Every child who learns or follows the learning process will shape and gain self-proficiency and appreciation in the child (Kunandar, 2012). Alternatively, it can be often referred to as learning outcomes or children's learning. It shows that the application of a combination of direct instruction and talking stick learning models using traditional angklung musical instruments can increase teacher activities and children's activities in learning.

\section{Conclusion and Recommendation}

As the results of research and discussion, it can be concluded that is:

1. Teacher activities per the steps that have been planned by getting a very good category.

2. Children's activities increase with the very active category.

3. The development of art individually can be said to be successful with the category of developing as expected and developing very well, then classically the results of the ability of children with a very well developed category.

Recommendations from this study are expected to increase the treasury of knowledge for early childhood education, particularly in developing aspects of the arts through traditional angklung instruments, including:

1. For Teachers: provide new insights/ knowledge in developing the abilities of aspects of children's art using a combination of direct instruction learning models and talking sticks with traditional angklung musical instruments.

2. For the Head of Kindergarten: this research can be used as an alternative material to foster teachers were developing aspects of art.

For further researchers, to increase knowledge and as a reference for further researchers, they can research more models in different locations and situations.

\section{Acknowledgment}

Thanks to the head of the program, the secretariat, and the lecturers of the Master of Teacher Education Program in Early Childhood Education at the University of Lambung Mangkurat, Banjarmasin. He provided input and suggestions for writing this article. Furthermore, thanks also to the Khadijatul Kubra Foundation and the Khadijatul Kubra Kindergarten Teacher in Banjarmasin City for helping with the smooth running of this research. May we all always be in the Blessing of Allah SWT. Amiin.

\section{References}

Afifah. N, Suriansyah. A, \& Aslamiah. (2019). Implementasi Kurikulum Berbasis Aqidah Islam Di Sekolah Tahfizh Plus TK Khoiru Ummah. j-K6EM, 2, 47-57.

AH, N. M. (2018). Cultivating entrepreneurial values to improve several aspects of early childhood development: The case study in khalifah kindergarten yogyakarta. International Journal on Islamic Educational Research, 2(1), 85-111.

Alizadeh, M. (2016). The impact of motivation on english language learning. International Journal of Research in English Education, 1(1), 11-15.

Aslamiah. (2016). Build a qualified education through development of elementary school's teacher's performance. $P S 2 D M P, 2(1), 1-10$.

Baharuddin, \& Dalle, J. (2017). Interactive courseware for supporting learners competency in practical skills. TOJET: The Turkish Online Journal of Educational Technology, 16(3), 1-13.

Baharuddin, B., \& Dalle, J. (2019). Transforming learning spaces for elementary school children with special needs. Journal of Social Studies Education Research, 10(2), 344-365.

Baiti, N., Metroyadi., \& Wahyu. (2019). Teaching Pattern, Economic Social, and Parents Communication against Children's Language Skills. j-K6EM, 2(1), 1-11.

Brussoni, M., Olsen, L. L., Pike, I., \& Sleet, D. A. (2012). Risky play and children's safety: Balancing priorities for optimal child development. International Journal of Environmental Research and Public Health, 9(9), 3134-3148. doi:10.3390/ijerph9093134

Chen, S. (2016). The importance of creative arts in early childhood education.

https://novakdjokovicfoundation.org/importancecreative-arts-ece/.

Christophersen, M. (2015). Securing Education for Syrian Refugees in Jordan (pp. 7-8, Rep.). International Peace Institute. 
Citrowati, E. (2019). The Effect of Playing Science on Cognitive Development. Proceedings of the International Conference of Early Childhood Education, 449, 80-83. doi:10.2991/assehr.k.200715.016

Coates, E., \& Coates, A. (2006). Young children talking and drawing. International Journal of Early Years Education, 14(3), 221-241. doi:10.1080/09669760600879961

Cope, C., \& Ward, P. (2002). Integrating learning technology into classrooms: The importance of teachers' perceptions. Journal of Educational Technology \& Society, 5(1), 67-74.

Cusick, S., \& Georgieff, M. (2013). 'The first 1,000 days of life: The brain's window of opportunity'. UNICEF.

Daugherty, L., Dossani, R., Johnson, E., \& Wright, C. (2014) Families, Powered On: Improving Family Engagement in Early Childhood Education Through Technology. In Families, Powered On: Improving Family Engagement in Early Childhood Education Through Technology (pp. 1-8). RAND Corporation.

Davison, C., \& Lazaros, E. (2015). Adopting Mobile Technology in the Higher Education Classroom. The Journal of Technology Studies, 41(1), 30-39.

Drummond, K., \& Stipek, D. (2004). Low-Income Parents' Beliefs about Their Role in Children's Academic Learning. The Elementary School Journal, 104(3), 197-213.

Eichsteller, G., \& Holthoff, S. (2012). The Art of Being a Social Pedagogue: Developing Cultural Change in Children's Homes in Essex. International Journal of Social Pedagogy, 1(4), 30-45. doi:10.14324/111.444.ijsp.2012.v1.1.004.

Eisner, E. W. (2004). What Can Education Learn from the Arts about the Practice of Education? International Journal of Education \& the Arts, 5(4), 1-13.

Erviana, R., Ahmad, K. I., \& Sari, N. P. (2020). Developing Cognitive Ability to Matching Numbers and Symbol Using a Combination of Models, Methods, and Media Learning. Journal of K6, Education and Management, 2(4), 271-282 .

Fatmasari, Darmiyati, \& Sulaiman. (2015). The use of direct instruction models in combination with the team game tournament (TGT) to improve learning outcomes of the properties of space building in class V SDN Kuin Cerucuk 3 Banjarmasin. Journal of Paradigm, 10(1), 1-8.

FLeer, M. (2011). 'Conceptual Play':foregrounding imagination and cognition during concept formation in early years education. Contemporary Issues in Early Childhood, 12(3), 224-240. doi:10.2304/ciec.2011.12.3.224

Fleer, M. (2011). Kindergartens in Cognitive Times: Imagination as a Dialectical Relation Between Play and Learning. International Journal of Early Childhood, 43, 245-259. doi:10.1007/s13158-011-0044-8
Gale, C. (2005). Commentary: Height and intelligence. International Journal of Epidemiology, 34(2), 678-678. doi:10.1093/ije/dyi064

Galindo, L., Maginnis, T., Wallace, G., Hansen, A., \& Sylvestre, D. (2007). Education by peers is the key to success. International Journal of Drug Policy, 18(5), 411-416. doi:10.1016/j.drugpo.2007.03.003

Goldfarb, K. (2017). Food, Affect, and Experiments in Care: Constituting a 'Household-like' Child Welfare Institution in Japan. In F. S. (Eds.), Child's Play: Multi-Sensory Histories of Children and Childhood in Japan (pp. 243-263). Oakland, California: University of California Press.

Gottfried, A. E., Preston, K. S., Gottfried, A. W., Oliver, P. H., Delany, D. E., \& Ibrahim, S. M. (2016). Pathways from parental stimulation of children's curiosity to high school science course accomplishments and science career interest and skill. International Journal of Science Education, 38(12), 1972-1995. doi:10.1080/09500693.2016.1220690

Hallam, S. (2010). The power of music: Its impact on the intellectual, social and personal development of children and young people. International Journal of Music Education, 28(3), 269-289. doi:10.1177/0255761410370658

Hamalik, O. (2005). Teaching Planning Based on Approach. System. Jakarta: Bumi Aksara.

Hidayat, A., Hadi, S., \& Darmiyati. (2019). Children's Cognitive Development in Pairing Numbers with its Symbols Through Demonstration Model of Combination, Make A Match with Help from Audio Visual Media in Group B RA Citra Islami Kindergarten Banjarmasin. J-K6EM, 1-16.

Hofstede, G. (1986). Cultural differences in teaching and learning. International Journal of Intercultural Relations, 10(3), 301320. doi:10.1016/0147-1767(86)90015-5

Hoover-Dempsey, K., Walker, J., Sandler, H., Whetsel, D., Green, C., Wilkins, A., \& Closson, K. (2005). Why Do Parents Become Involved? Research Findings and Implications. The Elementary School Journal, 106(2), 105-130.

Hsi, S. (2007). Conceptualizing Learning from the Everyday Activities of Digital Kids. International Journal of Science Education, 29(12), 1509-1529. doi:10.1080/09500690701494076

Huda, M. (2014). Teaching and Learning Models. Yogyakarta: Pustaka Pelajar.

Ilmim, B. (2018). KWARTET: PRESERVING THE CULTURE BY PLAYING IT. International Journal of Social Sciences, 4(2), 1233-1247. doi:10.20319/pijss.2018.42.12331247

Jimoyiannis, A. (2010). Designing and implementing an integrated technological pedagogical science knowledge framework for science teachers professional development. Computers \& Education, 55, 1259-1269. doi:10.1016/j.compedu.2010.05.022 
Kunandar. (2012). Easy Steps to Research Classroom Action as Teacher Professional Development. Jakarta: PT RajaGarfindo Persada.

Kurniasih, I., \& Sani, B. (2015). Variety of Learning Model Development for Improving Teacher Professionalism. Jogjakarta: Kata Pena.

Martin, L., Sontag-Padilla, L., Cannon, J., Chandra, A., Auger, A., Kase, C., \& . . . Spurlock, K. (2014). SOCIAL AND EMOTIONAL DEVELOPMENT In Child-Care Settings. In Off to a Good Start: Social and Emotional Development of Memphis' Children (pp. 33-40). Santa Monica, Calif: RAND Corporation.

Maufur, H. (2009). A million fun teaching skills. Jakarta: Sindur Press.

McCutchen, B. P. (2006). Teaching dance as art in education. America: Human Kinetics.

Meeson, P. (1974). Herbert Read's Definition of Art in "Education through Art". Journal of Aesthetic Education, 8(3), 5-18.

Metroyadi, \& Mardhiah, A. (2018). Efforts to Develop Children Fine Motor Skills Through Sticking Picture Properly By Using Combination of Explicit Instruction Model And Assignment Media Utilizing Natural Materials. J-K6EM, 1, 22.

Oreck, B. (2006). Artistic Choices: A Study of Teachers Who Use the Arts in the Classroom. International Journal of Education \& the Arts, 7(8), 1-27.

Pala, A. (2011). The Need For Character Education. International Journal of Social Sciences And Humanity Studies, 3(2), 2332.

Piaget, J. (1993). Physical Knowledge in Preschool Education: Implications of Piaget's Theory. New York: Teachers College Press.

Porath, O. (2017). Nasty Boys or Obedient Children?: Childhood and Relative Autonomy in Medieval Japanese Monasteries. In F. S. (Eds.), Child's Play: Multi-Sensory Histories of Children and Childhood in Japan (pp. 17-40). Oakland, California: University of California Press.

Rathunde, K., \& Csikszentmihalyi, M. (2005). Middle School Students' Motivation and Quality of Experience: A Comparison of Montessori and Traditional School Environments. American Journal of Education, 111(3), 341371.

Rogers, A. (2014). Interactions between Informal Learning and Formal/Non-Formal Learning. In The Base of the Iceberg: Informal Learning and Its Impact on Formal and Nonformal Learning (pp. 59-76). Opladen; Berlin; Toronto: Verlag Barbara Budrich.

Rosenthal, D., \& Lakhanpaul, M. (2020). Child health and homelessness. In C. C. (Eds.), Transforming Early Childhood in England: Towards a Democratic Education (pp. 34-53). London: UCL Press.
Safitri, M. E., Ahmad, K., \& Saleh, M. (2018). Development Of Child Independence Through Model Picture and Picture, Examples Non Examples Model and Practical Method Directly Activities of Learning Practical Life In Group B Kasih Ibu Kindergarten, Banjarmasin, Indonesia. European Journal of Education Studies, 5(7), 36-48.

Sakerebau, J. (2018). Understanding the role of educational psychology for learning. BIA Journal of Theology and Contextual Christian Education, 1(1), 96-111. doi:https://doi.org/10.34307/b.v1i1.22

Samuelsson, I. P., Carlsson, M. A., Olsson, B., Pramling, N., \& Wallerstedt, C. (2009). The art of teaching children the arts: music, dance and poetry with children aged 2-8 years old. International Journal of Early Years Education, 17(2), 119-135. doi:10.1080/09669760902982323

Sanjaya, W. (2009). Educational Process Standard Oriented Learning Strategy. Jakarta: Prenada.

Sheridan, S. M., Edwards, C. P., Marvin, C. A., \& Knoche, L. L. (2009). Professional Development in Early Childhood Programs: Process Issues and Research Needs. Earlu Education and Development, 20(3), 377-401. doi:10.1080/10409280802582795

Spektor-Levy, O., Baruch, Y. K., \& Mevarech, Z. (2013). Science and Scientific Curiosity in Pre-school-The teacher's point of view. International Journal of Science Education, 35(13), 2226-2253. doi:10.1080/09500693.2011.631608

Sujiono, Y. (2013). Basic concepts of early childhood education. Jakarta: PT. Indeks.

Sullivan, A. B. (2018). Dancing robots: integrating art, music, and robotics in Singapore's early childhood centers. Int J Technol Des Educ, 28, 325-346. doi:10.1007/s10798-0179397-0

Suriansyah, A. (2011). Education Foundation. Banjarmasin: Comdes.

Suriansyah, A., \& Aslamiah. (2011). Early Childhood Learning Strategy. Banjarmasin: Comdes.

Susanto, A. (2015). Learning Theory and Learning in Primary Schools. Jakarta: Kencana Prenadamedia Group.

Suyadi. (2010). Learning Psychology of Early Childhood Education. Yogyakarta: Pedagogia.

Thematic Group 4. (2014). The Future of Our Children: Lifelong, Multi-Generational Learning For Sustainable Development . Sustainable Development Solutions Network.

Van Loon, A., Ros, A., \& Martens, R. (2012). Motivated learning with digital learning tasks: What about autonomy and structure? Educational Technology Research and Development, 60(6), 1015-1032.

Walthall, A. (2017). For the Love of Children: Practice, Affect, and Subjectivities in Hirata Atsutane's Household. In W. A. (Eds.), Child's Play: Multi-Sensory Histories of Children and 
HN Ramdana, NP Sari, 2020 / Develop aspects of the art in playing traditional angklung using a combination learning model

Childhood in Japan (pp. 60-80). Oakland, California: Yus, A. (2011). Early childhood education model. Jakarta: Kencana. University of California Press. 